\title{
Yaniv, Bracha. Ceremonial Synagogue Textiles from Ashkenazi, Sephardi, and Italian Communities. London: The Littman Library of Jewish Civilization in association with Liverpool University Press, 2019.
}

\section{Reviewed by Annette B. Fromm, Miami Beach, Florida, USA.}

Bracha Yaniv has assembled a thorough documentation of ceremonial synagogue textile from every possible perspective in this beautifully illustrated book. Under consideration are the three items used to dress the Torah: wrapper, binder, and mantle in association with other textiles used in the synagogue. This recent volume, an updated translation of an earlier publication, is comprised of a weighty text along with heavily annotated plates/images.

The book is divided into three parts: Ceremonial Synagogue Textiles, Annotated Plates, and Dedication of Ceremonial Objects, followed by appendices. The author briefly presents background information related to the general evolution of synagogue textiles along with historic explanations. In addition, she provides an outline of the historic development of synagogue building in order to better understand the placement and function of the textiles.

Following this introduction is an in depth discussion of each type of item from Jewish communities of Europe, North Africa, and the former Ottoman Empire. As would be expected, the text is filled with discussions of language and the derivation of terms that have been used for these objects in Jewish communities worldwide.

In Part I, Yaniv first addresses the fabrics and techniques that have been used to create this rich repertoire of textiles providing insights into textile production especially of silks and brocades in Italy, the Balkans, and Anatolia. The text is the result of extensive study, rich description, and deep analysis of all aspects details related to ceremonial textiles from textile production and embroidery. The extent of her research is evident in the heavy footnotes which are, frankly, almost as rich in information as the text; they almost serving as a supplemental addition to the primary text of the book.

The primary ceremonial items under consideration are the Torah wrapper and binder, the mantle, the Torah ark curtain. Yaniv's analysis is supported by extensive discussions of rabbinic literature and responsa with regards to these items. Historic images drawn from early manuscripts or printed materials beautifully illustrate her text. The use of distressed or worn textiles in the production of

Women in Judaism: A Multidisciplinary Journal Volume 17 Number 2 (2020) ISSN 1209-9392 
some of the objects is a frequent topic. Elsewhere, she writes about the structural relationship between synagogue textiles and clothing using schematics of mantle design to illustrate the relationship to contemporaneous cloaks worn by men and women.

Like many curators and probably museum visitors, I have long been entranced by the entertaining and skillfully embroidered and painted German Torah binders known as wimples. Yaniv considers the evolution of the range of images used on these items. Derived from a cloth used to hold a male baby at the time of his circumcision, then reworked to be donated to a synagogue for use with the Torah, this textile is literally the tie that binds. I had wished that she has included sketches of wimple-type Torah binders similar to those of the mantles.

The rich descriptive and illustrated text is followed in Part II by a selection of annotated plates of a number of representative items the author discussed. These are close up, color images organized by country or community. Through the camera's lens she is able to dissect the textiles she has thoroughly discussed in Part I. Each section starts with a summary of the synagogue textile being discussed and their functions. For example, Italian textiles shown in greater detail include wrappers, binders, and mantles. In the annotated images, close-ups of the segments of a number of German wimple-type binders are shown.

In Part III, Yaniv focuses on customs associated with the dedications which were embroidered or otherwise inscribed on many of the textile objects. She addresses the purpose of dedications found on the various textiles and how they can reveal insights into different aspects of a community. Once again she reaches to past practices associated with ritual objects used in biblical times to carefully unlock the content and circumstances of the dedication. She often gives very detailed analyses of phrases and wording.

The book closes with interesting appendices that provide hints into the volume and variety of synagogue textiles in the areas included. First are a number of historical inventories from select synagogues or communities, such as ceremonial objects including textiles from the Great Synagogue of Vila, 1634, textiles from Jewish communities of Poland pre WWI, and textiles in synagogues of Izmir, ca. 1949. Second is a handful of documents relating to textiles from seventeenth-century Vilna to present day Morocco followed by miscellaneous inventories dating from the sixteenth century to the twentieth century. The origins of some of the items included in 


\section{Book Review}

this closing section are included. Others have no explanation. The book concludes with a Glossary, extensive bibliography, list of collections where these ceremonial textiles are housed and more.

Ceremonial Synagogue Textiles from Ashkenazi, Sephardi, and Italian Communities is not a mere description or history of these objects. It showcases the depth of knowledge of a research of an author who has been studying and writing about these subjects for many years. The amply illustrated text reflects her long-time, exhaustive work with Jewish textiles. It will surely be of use to students of the subject as a reference as well as lovers of historic synagogue textiles. 